\title{
Respon Kebijakan: Mitigasi Dampak Wabah Covid-19 Pada Sektor Pariwisata
}

\author{
I Dewa Gde Sugihamretha ${ }^{1}$
}

Kementerian Perencanaan Pembangunan Nasional/Bappenas Republik Indonesia

\begin{abstract}
Abstraksi
Wabah Covid-19 memberikan dampak yang parah terhadap sektor pariwisata, setelah sebelumnya sektor ini mengalami serangan wabah serupa dan berbagai cobaan lain namun dapat bangkit kembali. Wabah Covid-19 berdampak lebih berat. Makalah ini mempelajari respon kebijakan wabah Covid-19 terhadap sektor pariwisata dengan mempelajari data dan tindakan-tindakan yang telah dilakukan di sejumlah negara, untuk sebagian diusulkan agar dapat diterapkan di Indonesia. Hal ini sangat penting karena pariwisata menyangkut tenaga kerja yang banyak, dan peranannya secara ekonomi sedang didorong oleh pemerintah Indonesia. Tujuan respon kebijakan yang diusulkan agar penanganan krisis dapat dilakukan dengan baik, dan wisatawan segera kembali lagi di Indonesia.
\end{abstract}

Kata Kunci: Covid-19; Pariwisata Indonesia; Respon Kebijakan

\footnotetext{
${ }^{1}$ I Dewa Gde Sugihamretha adalah Perencana Utama di Kementerian Perencanaan Pembangunan Nasional/Bappenas RI. E-mail: gde@bappenas.go.id
}

The Indonesian Journal of Development Planning 


\title{
Respon Kebijakan: Mitigasi Dampak Wabah Covid-19 Pada Sektor Pariwisata
}

\author{
I Dewa Gde Sugihamretha
}

\section{Latar Belakang}

Dalam kurun waktu sepuluh tahun terakhir tahun 2009-2019, pariwisata dunia terus mengalami peningkatan. Wisatawan internasional (international tourist) meningkat dari 892 juta orang pada saat masa krisis tahun 2009 menjadi 1. 461 juta orang pada tahun 2019. Indikator kinerja lain menunjukkan nilai strategis dari pariwisata dunia tahun 2019 antara lain: pertumbuhan $4 \%$; satu dari sepuluh lapangan kerja di dunia diisi pekerja dari sektor pariwisata; berkontribusi 7\% dari ekspor global (Gambar 1).

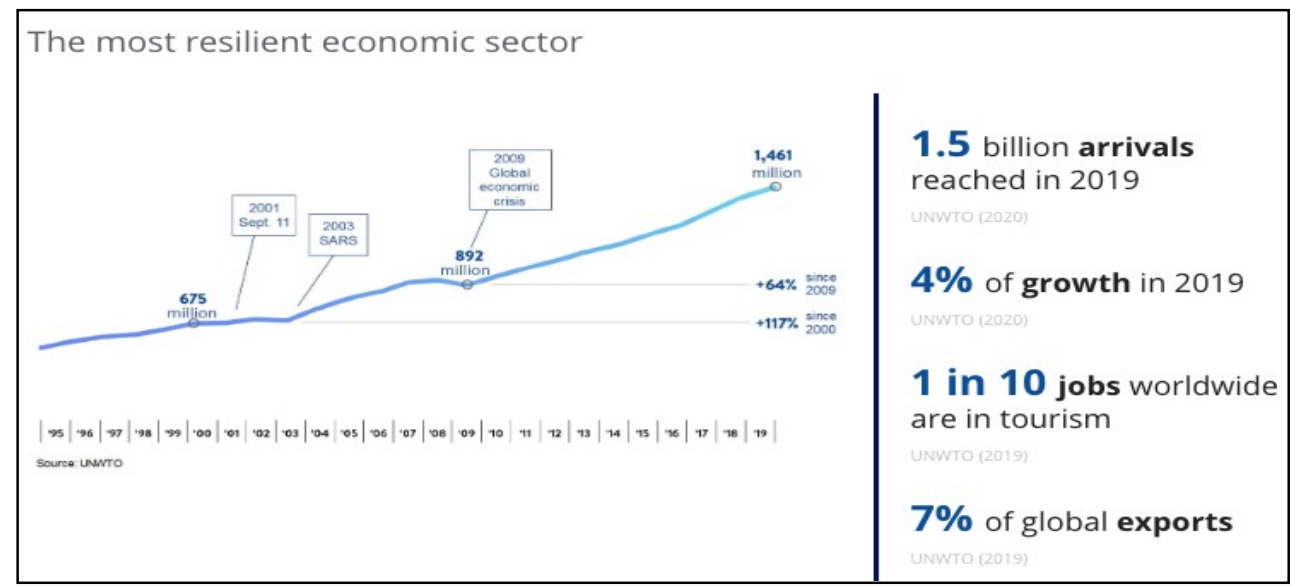

Gambar 1. Perkembangan Pariwisata Dunia Tahun 1995-2019

Sumber: UNWTO

Covid-19 adalah wabah global yang berdampak buruk pada dimensi manusia dan sosial. Setelah menyebar dari Cina, pandemi meluas dengan cepat ke 210 negara termasuk Indonesia. Pandemi Covid-19 adalah kejutan besar bagi ekonomi global termasuk Indonesia. Ekonomi mengalami penurunan setidaknya untuk paruh pertama tahun ini dan mungkin lebih lama jika tindakan penahanan wabah Covid-19 tidak efektif.

Pandemi Covid-19 menyebabkan gangguan pada rantai pasok global, dalam negeri, volatilitas pasar keuangan, guncangan permintaan konsumen dan dampak negatif di sektorsektor utama seperti perjalanan dan pariwisata. Dampak wabah Covid-19 tidak diragukan lagi akan terasa di seluruh rantai nilai pariwisata. Perusahaan kecil dan menengah diperkirakan akan sangat terpengaruh.

Tekanan pada industri pariwisata sangat terlihat pada penurunan yang besar dari kedatangan wisatawan mancanegara dengan pembatalan besar-besaran dan penurunan pemesanan. Penurunan juga terjadi karena perlambatan perjalanan domestik, terutama karena keengganan masyarakat Indonesia untuk melakukan perjalanan, khawatir dengan dampak Covid-19. Penurunan bisnis pariwisata dan perjalanan berdampak pada usaha UMKM, dan terganggunya lapangan kerja. Padahal selama ini pariwisata merupakan sektor padat karya yang menyerap lebih dari 13 juta pekerja. Angka itu belum termasuk dampak turunan atau multiplier effect yang mengikuti termasuk industri turunan yang terbentuk di bawahnya.

The Economist merevisi prediksi pertumbuhan ekonomi untuk semua negara-negara anggota G20. Hasilnya, wabah Covid-19 membawa hampir seluruh negara G20 jatuh ke 
jurang resesi. Lebih dari setengah negara G20 diprediksi mengalami pertumbuhan ekonomi negatif. The Economist memperlihatkan hanya 3 negara G20 yang diprediksi masih menunjukkan pertumbuhan ekonomi positif sepanjang 2020 yaitu Indonesia, Cina, dan India. Untuk Indonesia, The Economist memprediksi pertumbuhan PDB riil pada tahun 2020 berada di angka 1 persen, sementara prediksi pertumbuhan PDB Indonesia sebelum Covid19 adalah 5,1 persen.

Bank Indonesia juga mengoreksi proyeksi pertumbuhan ekonomi dari 5,0-5,4 persen menjadi 4,2-4,6. Perubahan proyeksi pertumbuhan akibat dari melambatnya prospek pertumbuhan ekonomi dunia yang hanya 2,5 persen menurunkan prospek pertumbuhan ekspor barang Indonesia; perlambatan ekonomi sejumlah negara seperti ekonomi AS yang diperkirakan hanya tumbuh 1,6 persen dan China tumbuh 5,1 persen; ekspor jasa terutama sektor pariwisata diperkirakan juga menurun akibat terhambatnya proses mobilitas antarnegara.

Makalah "Respon kebijakan: mitigasi dampak Covid-19 di sektor pariwisata” ini mencoba menjawab beberapa pertanyaan seperti:

1. Apa tantangan terbesar dalam menavigasi Covid-19?

2. Bagaimana mengurangi dampaknya?

3. Langkah apa yang penting difokuskan saat ini?

4. Bagaimana menavigasi komunikasi internal dengan tenaga kerja dan pemangku kepentingan utama?

5. Tindakan apa yang penting diambil sekarang guna memastikan wisatawan akan kembali setelah krisis Covid-19 usai?

\section{Analisis dan Pembahasan}

\section{a) Pariwisata Dunia}

Organisasi pariwisata dunia (UNWTO) pada bulan Maret 2020 mengumumkan bahwa dampak wabah Covid-19 akan terasa di seluruh rantai nilai pariwisata. Sekitar $80 \%$ usaha kecil dan menengah dari sektor pariwisata dengan jutaan mata pencaharian di seluruh dunia terkena dampak Covid-19. Dalam merespon wabah Covid-19, UNWTO telah merevisi prospek pertumbuhan wisatawan internasional negatif $1 \%$ hingga $3 \%$. Hal ini berdampak pada menurunnya penerimaan atau perkiraan kerugian US \$ 30 miliar sampai dengan US \$ 50 miliar. Sebelum wabah Covid-19, wisatawan internasional diperkirakan tumbuh antara $3 \%$ sampai $4 \%$. Asia dan Pasifik akan menjadi wilayah yang terkena dampak terburuk, dengan penurunan kedatangan yang diperkirakan antara $9 \%$ hingga $12 \%$.

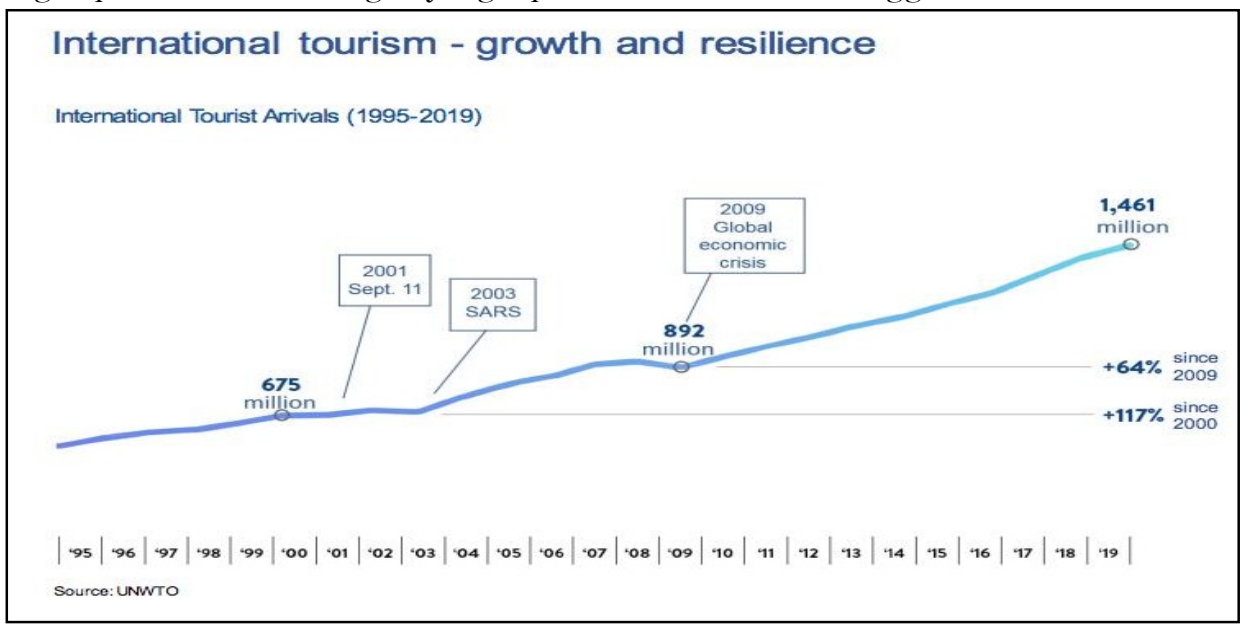


Gambar 2. International Tourism-Growth and Resilience

Pada Maret 2020, UNWTO melakukan penilaian dampak wabah Covid-19 terhadap wisatawan internasional. Dari hasil assessement nampak bahwa perkembangan wisatawan internasional sejak tahun 1995 terus mengalami pertumbuhan dengan menunjukkan kekuatan dan ketahanan menghadapi guncangan seperti SARS pada tahun 2003, dan krisis ekonomi global disertai dengan perang Irak pada tahun 2009. Badai ini dapat diatasi dengan cepat sehingga sampai tahun 2019 jumlah wisatawan mancanegara meningkat menjadi 1,461 juta orang (Gambar 2).

Sampai hari ini, belajar dari pengalaman menangani wabah SARS dilihat dari sisi ukuran, dinamika pasar perjalanan global, penyebaran geografis COVID-19 dan potensi dampak ekonominya, UNWTO memperkirakan kedatangan wisatawan internasional bisa menurun sebesar $1 \%$ hingga $3 \%$ pada tahun 2020 secara global, atau turun dari perkiraan pertumbuhan 3\% hingga 4\% pada awal Januari 2020 (Gambar 3, dan Gambar 4).

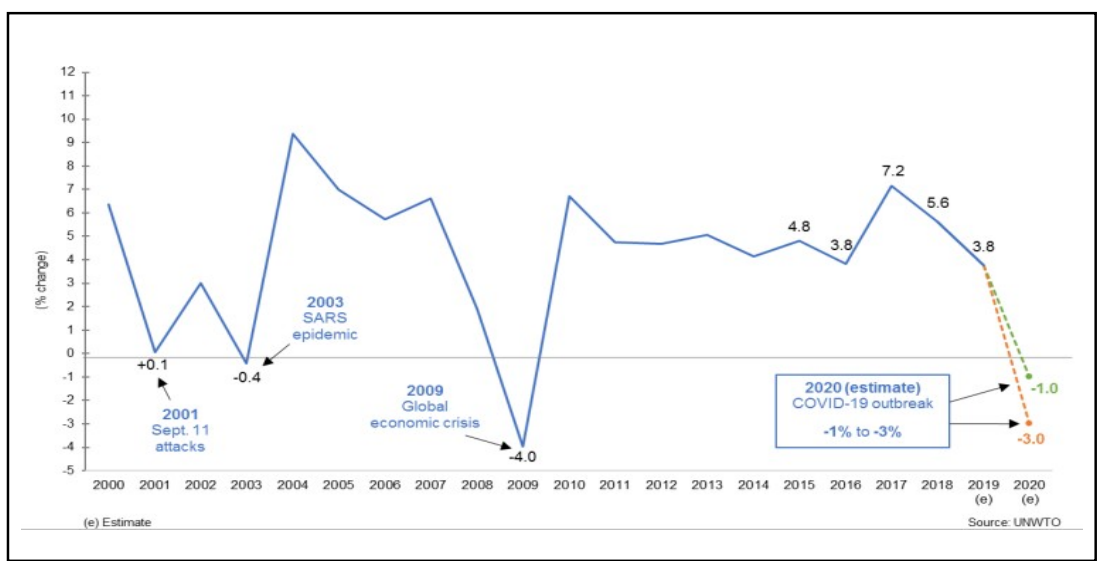

Gambar 3. Revised 2020 forecast - international tourist arrivals, world (\% change)

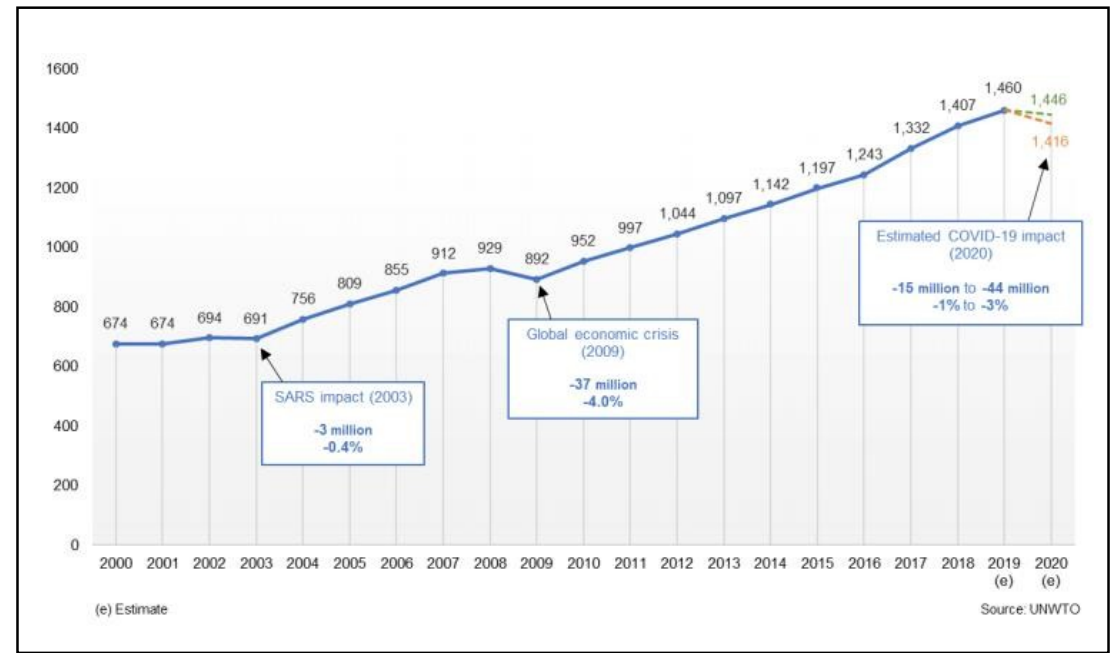

Gambar 4. Revised 2020 forecast - international tourist arrivals, world (million) 


\section{b) Pariwisata Indonesia}

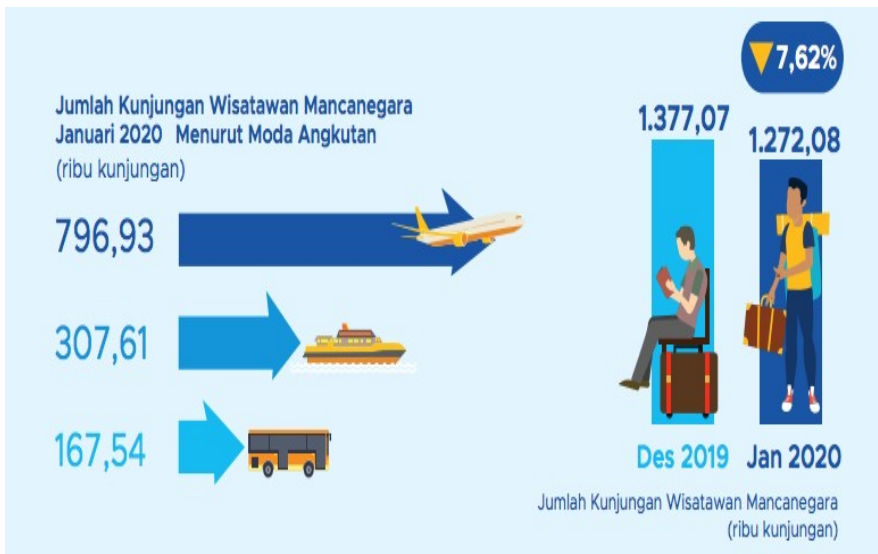

Gambar 5. Jumlah kunjungan Wisman Menurut Moda Angkutan Januari 2020 Badan

Pusat Statistik (BPS) mencatat kunjungan wisatawan mancanegara (wisman)

yang datang ke Tanah Air pada awal tahun 2020 mengalami penurunan. Selama Januari 2020, kunjungan wisman mencapai sebanyak 1,27 juta kunjungan. Angka ini merosot 7,62 persen bila dibandingkan jumlah kunjungan turis asing pada Desember 2019 sebanyak 1,37 juta kunjungan. Penurunan jumlah kunjungan turis asing ini utamanya disebabkan oleh mewabahnya Covid-19 yang terjadi pada pekan terakhir Januari 2020.

Merosotnya kunjungan turis asing ke Indonesia itu terlihat juga dari data wisman yang datang melalui pintu masuk udara (bandara). Jika dibandingkan dengan kunjungan pada Desember 2019, jumlah kunjungan wisman ke Indonesia melalui pintu masuk udara pada Januari 2020 mengalami penurunan sebesar 5,01 persen.
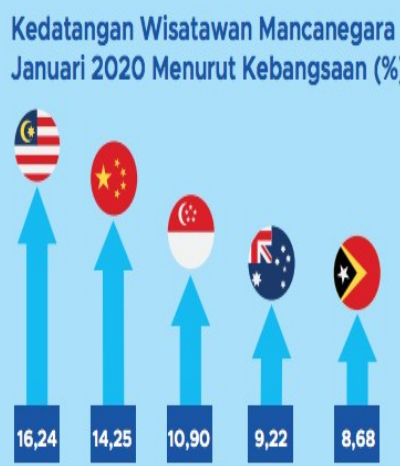

MALAYSIA TIONGKOK SINGAPURA AUSTRALIA TINORLESTE
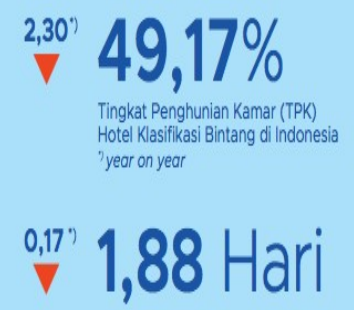

Rata-rata lama menginap tamu asing dan Indonesia pada Hotel Klasifikasi Bintang di Indonesia "year on year

Gambar 6. Kedatangan Wisman Menurut Kebangsaan Januari 2020

Tingkat Penghunian Kamar (TPK) hotel klasifikasi bintang di Indonesia pada Januari 2020 mencapai rata-rata 49,17 persen atau turun 2,30 poin dibandingkan dengan TPK Januari 2019 yang tercatat sebesar 51,47 persen. Begitu pula, jika dibanding TPK Desember 2019, TPK hotel klasifikasi bintang pada Januari 2020 mengalami penurunan sebesar 10,22 poin. Rata-rata lama menginap tamu asing dan Indonesia pada hotel klasifikasi bintang selama Januari 2020 tercatat sebesar 1,88 hari, terjadi penurunan sebesar 0,17 poin jika dibandingkan keadaan Januari 2019. 
Industri pariwisata dihadapkan pada penurunan yang besar dari kedatangan wisatawan mancanegara dengan pembatalan besar-besaran dan penurunan pemesanan. Penurunan juga terjadi karena perlambatan perjalanan domestik, terutama karena keengganan masyarakat untuk melakukan perjalanan. khawatir dengan dampak Covid-19. Penurunan bisnis pariwisata dan perjalanan berdampak pada usaha UMKM, dan terganggunya lapangan kerja. Padahal selama ini pariwisata merupakan sektor padat karya yang menyerap lebih dari 13 juta pekerja. Angka itu belum termasuk dampak turunan atau multiplier effect yang mengikuti termasuk industri turunan yang terbentuk di bawahnya.

Turunnya wisman terutama ke Indonesia akan berpengaruh terhadap penerimaan devisa dari pariwisata. Kurang lebih turun USD 1,3 miliar penerimaan devisa dari pariwisata. Tiongkok sebagai Negara asal wisatawan mancanegara terbanyak kedua di Indonesia.

Berdasar data Survei Tenaga Kerja Nasional (Sakernas), tenaga yang terserap pada usaha-usaha pariwisata terus meningkat. Bukan hanya dari jumlah tenaga kerja, pangsa (share) pariwisata terhadap penyerapan tenaga kerja nasional juga terus meningkat. Ini menunjukkan bahwa pariwisata dapat menjadi salah satu alternatif untuk mengurangi tingkat pengangguran. Pada tahun 2017 jumlah tenaga kerja pada industri pariwisata mencapai 12,74 juta orang atau 10,53 persen terhadap total tenaga kerja nasional yang berjumlah 121,02 juta orang.

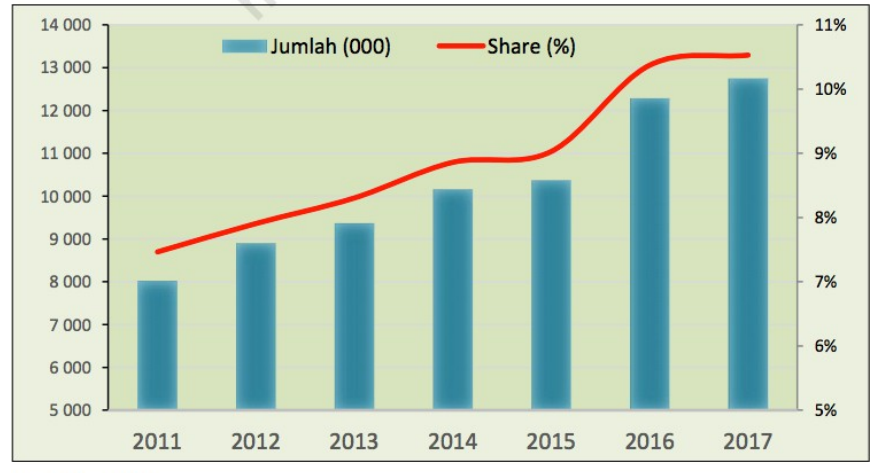

Sumber: BPS

Gambar 7. Jumlah Tenaga Kerja pada Usaha Pariwisata, Tahun 2011-2017

Dari 12,74 juta orang yang bekerja pada usaha pariwisata, porsi terbesar (30,57 persen) merupakan mereka yang berstatus berusaha sendiri, sementara yang berstatus berusaha dibantu buruh, baik dibayar maupun tidak dibayar, dan sebagai karyawan/buruh masing-masing sebesar 27,66 persen dan 24,23 persen. Untuk yang berstatus sebagai pekerja tidak dibayar mencapai 16,17 persen. Sedangkan untuk yang berstatus sebagai pekerja bebas hanya sebesar 1,36 persen.

Menurut lapangan usaha, usaha pariwisata yang menyerap tenaga kerja paling besar adalah usaha penyedia makan minum dan perdagangan yang masing-masing mempunyai pangsa mencapai 48,79 persen dan 36,76 persen. Hal ini dapat dipahami, selain karena jumlah usahanya yang relatif banyak dan tersebar, kedua usaha ini juga sangat berkaitan dengan aktivitas para wisatawan dalam perjalanan yang mereka lakukan, baik sebelum, selama perjalanan, maupun setelah melakukan perjalanan. Lapangan usaha lain yang cukup besar kontribusinya dalam penyerapan tenaga kerja adalah usaha penyediaan akomodasi dan kegiatan olah raga dan rekreasi lainnya yang masing-masing menyumbang 7,20 persen dan 1,94 persen. Sementara kegiatan hiburan, kesenian dan kreativitas menyumbang 1,54 persen. Usaha angkutan dan jasa agen perjalanan wisata mempunyai kontribusi masing-masing sebesar 0,56 persen dan 0,64 persen. 
Tabel 1. Jumlah Tenaga Kerja pada Usaha Pariwisata Menurut Lapangan Usaha, Tahun 2017

\begin{tabular}{lrr}
\multicolumn{1}{c}{ Lapangan Usaha } & $\begin{array}{c}\text { Jumlah } \\
\text { (000 org) }\end{array}$ & $\begin{array}{c}\text { Distribusi } \\
(\%)\end{array}$ \\
\hline 01) Perdagangan & \multicolumn{1}{c}{$(2)$} & \multicolumn{1}{c}{$(3)$} \\
02. Angkutan & 4682,5 & 36,76 \\
03. Penyediaan Akomodasi & 71,0 & 0,56 \\
04. Penyediaan Makan minum & 917,1 & 7,20 \\
05. Jasa Agen Perjalanan & 6215,0 & 48,79 \\
06. Kegiatan Hiburan, Kesenian dan & 81,5 & 0,64 \\
$\quad$ Kreativitas & 196,3 & 1,54 \\
07. Perpustakaan, Arsip, Museum dan & 43,6 & 0,34 \\
Kegiatan Kebudayaan Lainnya & & \\
08. Kegiatan Olahraga dan Rekreasi & 247,5 & 1,94 \\
$\quad$ Lainnya & 284,9 & 2,24 \\
09. Lainnya & 12739,4 & 100,00 \\
\hline$\quad \quad$ Jumlah & &
\end{tabular}

Sumber: BPS, 2016

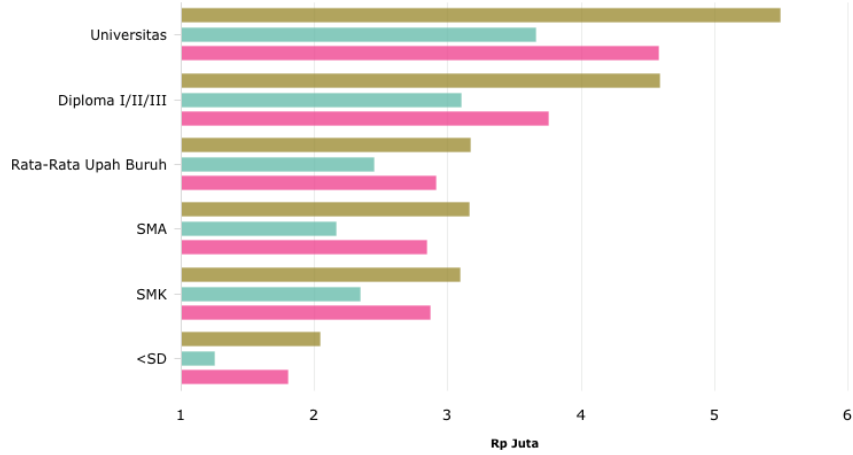

Gambar 8. Rata-Rata Gaji Pekerja Berdasarkan Jenjang Pendidikan, Agustus 2019

Sumber: Badan Pusat Statistik (BPS), 5 November 2019

Badan Pusat Statistik (BPS) mencatat rata-rata gaji atau upah yang diterima pekerja pada Agustus 2019 sebesar Rp 2,91 juta. Pekerja laki-laki dan yang berpendidikan tinggi mendapat upah lebih besar. Komposisi berdasarkan gender masih lebih tinggi laki-laki sebesar Rp 3,17 juta. Sementara gaji yang diterima perempuan dibawah rata-rata, yaitu sebesar Rp 2,45 juta. Jika dibandingkan dengan survei sebelumnya, angka ini lebih tinggi dari Februari 2019. Rata-rata gaji pada Februari 2019 sebesar Rp 2,79 juta dengan 3,05 juta laki-laki dan 2,34 juta perempuan. Berdasarkan hasil survei BPS, semakin tinggi jenjang pendidikan pekerja, semakin besar kisaran gaji yang diterima. Pekerja lulusan universitas mendapatkan gaji sebesar Rp 4,58 juta, sedangkan untuk tamatan SD hanya Rp 1,8 juta. Hal ini berarti, pekerja yang berpendidikan tinggi menerima upah 2,5 kali lipat lebih tinggi dibandingkan pekerja berpendidikan SD ke bawah. 


\section{Permasalahan}

Walaupun belum pasti, namun beberapa perkiraan menyebutkan bahwa puncak Covid-19 adalah sekitar bulan April, lalu mereda setelahnya, seperti yang terjadi pada kasus wabah yang lain yaitu SARS (Januari-April 2003) dan MERS (Januari-April 2014). The Economist memprediksi pemulihan ekonomi bisa saja terjadi pada semester II tahun 2020. Kasus-kasus wabah virus SARS, MERS, dan wabah virus lainnya seharusnya bisa menjadi pembelajaran baik untuk kesiapsiagaan dalam mengatasi dengan cepat munculnya wabah virus berikutnya seperti Covid-19 yang berdampak pada sektor pariwisata. Adapun beberapa permasalahan untuk dapat merespon dengan cepat mitigasi dampak Covid-19 di sektor pariwisata sebagai berikut:

1. Belum tersedia standard baku tata kelola tentang perencanaan, pelaksanaan, dan pengendalian dampak wabah/bencana di sektor pariwisata. Mengingat yang terlibat dalam rantai bisnis pariwisata sangat kompleks. Hal ini penting diperbaiki agar mitigasi wabah/bencana ke depan lebih baik dan semakin nyata. Transparansi, partisipasi dan akuntabilitas dalam inter-relasi para pihak baik pemerintah, masyarakat dan dunia usaha akan amat menentukan seperti apa kualitas dan keberhasilan dari suatu aktivitas penanganan wabah/bencana.

2. Lemahnya dukungan teknologi untuk memetakan data dasar by name, by address mengenai tenaga kerja pelaku industri-industri yang terkait pariwisata, seperti usaha jasa penyediaan akomodasi, penyediaan makanan dan minuman, tour and travel, dan usaha hiburan dan rekreasi. Hal ini mengakibatkan sulit dalam penyusun perencanaan untuk menghitung kebutuhan dukungan dana bagi tenaga kerja yang terdampak dan terkendala dalam pendistribusiannya.

3. Lemahnya koordinasi lintas sektor, lintas wilayah baik dalam pemerintahan maupun berbagai asosiasi industri pariwisata dari tingkat pusat sampai ke tingkat daerah.

4. Belum ada kelembagaan yang khusus menangani mitigasi dampak bencana di sektor pariwisata. Mengingat pariwisata dalam lima tahun ke depan menjadi prioritas nasional dan Negara kita adalah Negara cincin api Pasifik atau lingkaran api Pasifik (rink of fire), sebagai daerah yang sering mengalami gempa bumi dan letusan gunung berapi maka keberadaan kelembagaan ini sangat penting.

5. Rendahnya kemampuan pendanaan untuk penanggulangan bencana disektor pariwisata.

\section{Respon Kebijakan}

\section{a) Pembelajaran dari Cina-Asia}

Cina sebagai Negara yang mengawali penyebaran covid-19, saat ini secara perlahan telah mampu mengatasi permasalahan yang dihadapinya dengan berbagai respon kebijakan seperti: Pembebasan tarif impor untuk peralatan pengendalian epidemi, Bank sentral menggelontorkan liquiditas, pembayaran utang dan asuransi untuk perusahaan yang terkena dampak, pelonggaran kebijakan moneter, distribusi daging beku cadangan nasional, bank sentral menurunkan suku bunga. 


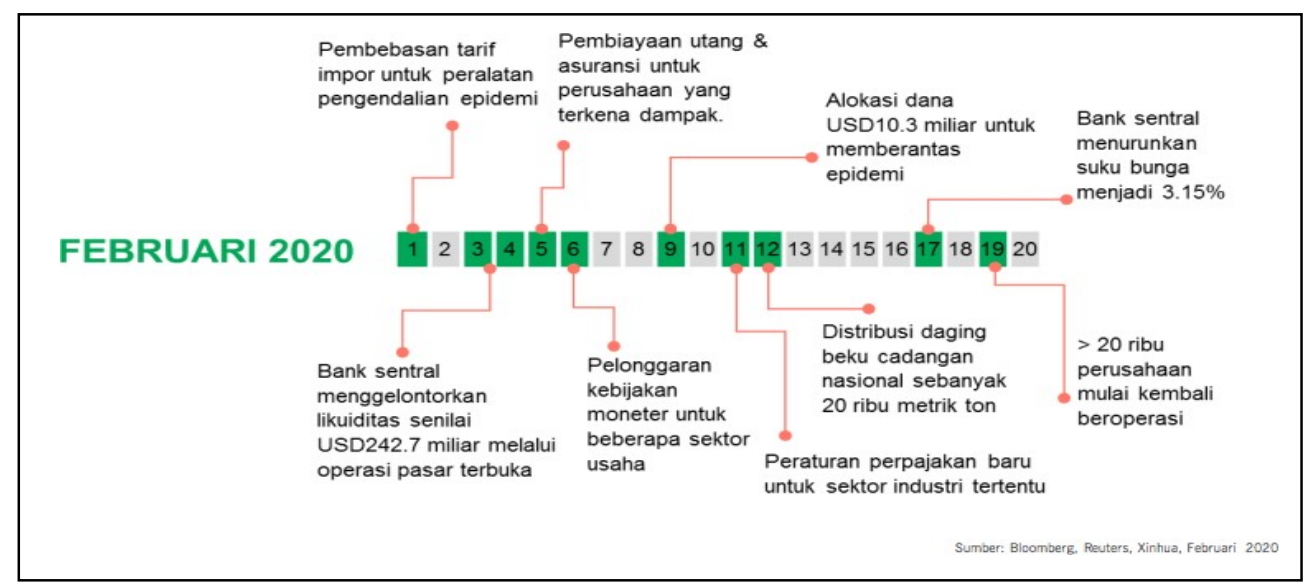

Gambar 10. Respon Kebijakan Fiskal dan Moneter-China.

Setelah menyebar dari Cina, pandemi meluas dengan cepat ke berbagai belahan dunia termasuk Indonesia. Berbagai bentuk intervensi kebijakan dikeluarkan oleh Negara yang terkena wabah Covid-19 seperti Nampak pada Gambar 11, bagaimana respon kebijakan fiskal dan moneter dari Negara-negara dibelahan Asia seperti: memberikan stimulus dan penurunan suku bunga pada tingkatan yang berbeda.

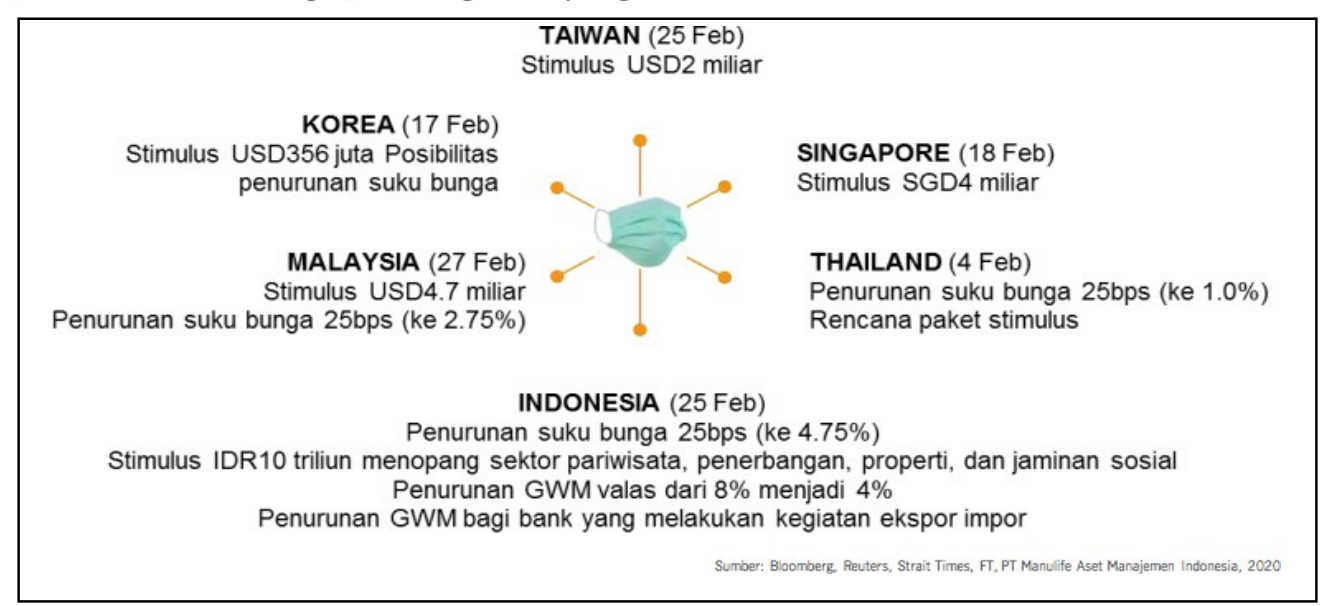

\section{Gambar 11. Respon Kebijakan Fiskal dan Moneter-Asia}

Pemerintah Indonesia telah menetapkan paket kebijakan mengakselerasi kinerja sektor pariwisata sekaligus untuk menarik kunjungan wisatawan di tengah wabah virus corona sebagaimana diuraikan pada Tabel 2 . 
Tabel 2. Kebijakan Mengakselerasi Kinerja Sektor Pariwisata

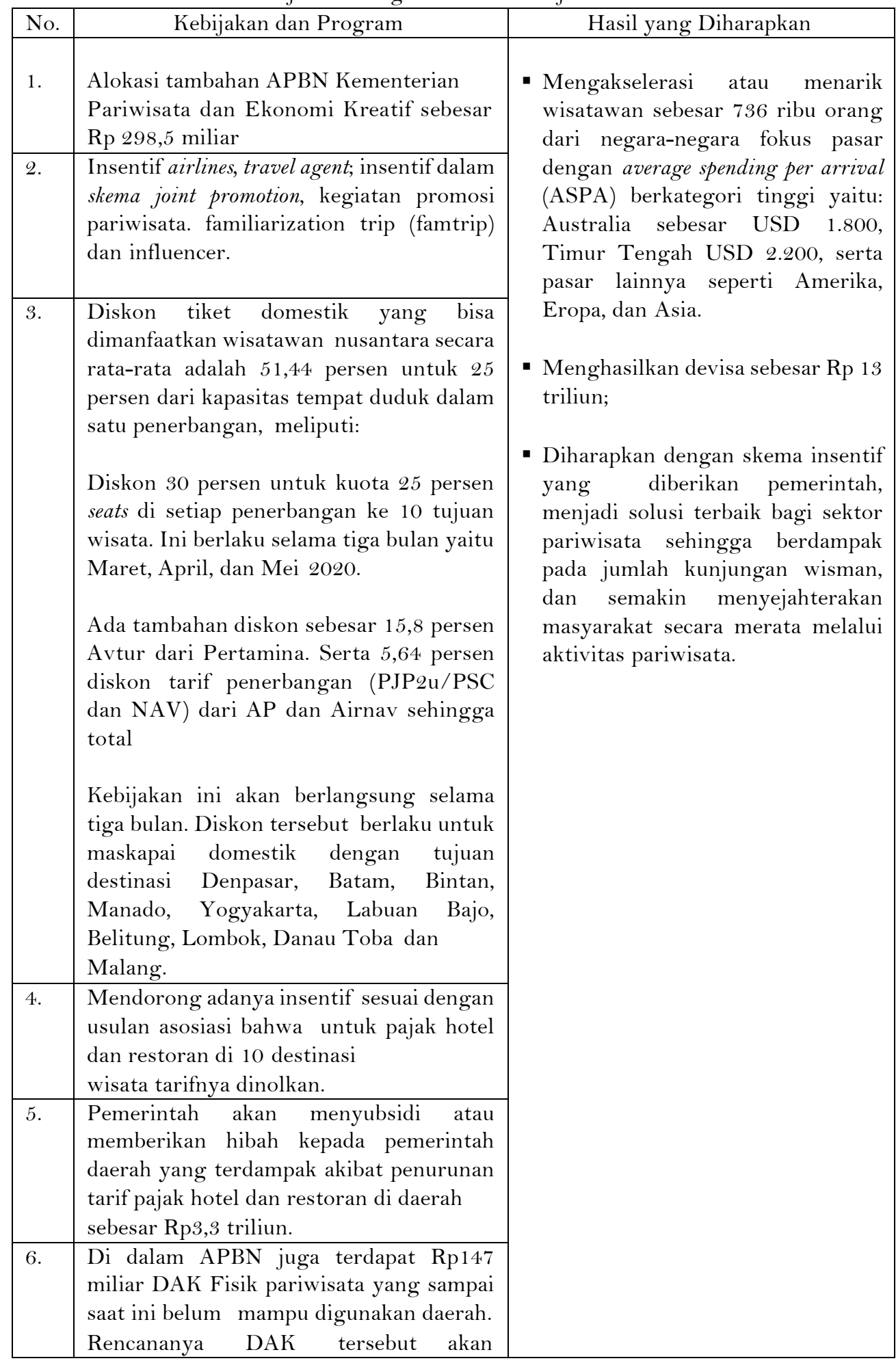




\begin{tabular}{|l|l|l|}
\hline & $\begin{array}{l}\text { dikonversi menjadi hibah ke daerah } \\
\text { sehingga bisa memacu perkembangan } \\
\text { pariwisata }\end{array}$ & \\
\hline 7. & $\begin{array}{l}\text { Mendorong pergerakan wisnus dengan } \\
\text { terus melakukan kampanye promosi } \\
\text { wisata dalam negeri, mendorong } \\
\text { dilakukannya pertemuan-pertemuan dari } \\
\text { instansi pemerintah dan korporasi di } \\
\text { destinasi-destinasi wisata dalam negeri. }\end{array}$ \\
\hline 8. & $\begin{array}{l}\text { Mempromosikan event-event (musik, } \\
\text { olahraga) yang sudah ada di dalam negeri. } \\
\text { Di sisi lain juga dilakukan upaya untuk } \\
\text { menarik potensi MICE dan event } \\
\text { internasional agar bisa diselenggarakan } \\
\text { di Indonesia. }\end{array}$ \\
\hline
\end{tabular}

\section{b) Pembelajaran dari Negara Eropa dan Negara Lain}

Beberapa negara telah merancang dan melaksanakan kebijakan untuk menyelamatkan kesinambungan pembangunan pariwisata. Dalam Tabel 3 ditunjukkan sejumlah negara yang telah mengumumkan dan sekarang menerapkan kebijakan yang mengesankan di bidang pariwisata.

Tabel 3. Paket Kebijakan Beberapa Negara Dalam Memitigasi Sektor Pariwisata dari Dampak Wabah Covid-19

\begin{tabular}{|c|c|c|}
\hline No. & Negara & Paket Kebijakan \\
\hline 1. & Itali & $\begin{array}{l}\text { Sebagai bagian dari paket "Italy Cure" package. Dalam paket kebijakan } \\
\text { ini, pemerintah memberikan perlindungan pada pekerja dengan } \\
\text { membayar } 80 \% \text { dari gaji karyawan, pekerja musiman dapat } \\
\text { mengajukan pembayaran khusus } € 600 \text { pada bulan Maret, keluarga } \\
\text { dapat mengajukan izin untuk menangguhkan pembayaran hipotek } \\
\text { mereka jika penutupan bisnis yang disebabkan oleh pandemi } \\
\text { mengancam mata pencaharian mereka, cuti telah diperpanjang } \\
\text { menjadi } 15 \text { hari pada bulan Maret dan April, orang yang merawat } \\
\text { orang yang dicintai penyandang cacat berhak untuk mengambil cuti } \\
12 \text { hari sebulan. Italia juga telah menyiapkan dana 500 juta Euro } \\
\text { untuk menangani kerusakan yang diderita oleh industri } \\
\text { penerbangan dan operasi Alitalia. }\end{array}$ \\
\hline 2. & Hongkong & $\begin{array}{l}\text { Untuk memastikan kesinambungan bisnis dalam Travel and Tourism, } \\
\text { Hongkong telah menciptakan Skema Dana Subsidi Agen Perjalanan } \\
\text { Anti Epidemik di mana sekitar } 1.350 \text { acara perjalanan telah } \\
\text { menerima pembayaran untuk membantu mereka mengatasi kesulitan } \\
\text { keuangan yang datang dari wabah. Setiap agen perjalanan yang } \\
\text { memenuhi syarat dapat menerima subsidi sekali saja sebesar HK } \$ \\
\text { 80.000. 98\% dari semua agen perjalanan berlisensi di Hongkong } \\
\text { telah mendaftar. }\end{array}$ \\
\hline
\end{tabular}




\begin{tabular}{|c|c|c|}
\hline 3. & Germany & $\begin{array}{l}\text { Untuk melindungi perusahaan-perusahaannya dari kebangkrutan, } \\
\text { pemerintah menjanjikan uang tunai tak terbatas untuk bisnis Jerman } \\
\text { dan menangguhkan kewajiban hukum bagi perusahaan yang } \\
\text { menghadapi masalah likuiditas akut untuk mengajukan kepailitan } \\
\text { hingga September. } \\
\text { Bantuan likuiditas pemerintah melalui Bank Pembangunan Negara } \\
\text { dalam bentuk pinjaman yang disediakan oleh KfW, dari } € 460 \text { milyar } \\
\text { sampai } € 55 \text { omilyar ( } \$ 610 \text { miliar). }\end{array}$ \\
\hline 4. & Australia & $\begin{array}{l}\text { Sebagai bagian dari rencana stimulus } \$ 10,3 \text { miliar (AUS } \$ 17,6 \\
\text { miliar) dan tambahan } \$ 38,3 \text { miliar untuk dibelanjakan selama enam } \\
\text { bulan ke depan, pemerintah telah menjanjikan AUS } \$ 1 \text { miliar (US } \$ \\
613 \text { juta) untuk mendukung sektor-sektor, kawasan dan komunitas, } \\
\text { termasuk bisnis Tourism \& Travel yang terkena dampak covid-19. } \\
\text { Pembebasan biaya dan ongkos untuk bisnis pariwisata yang } \\
\text { beroperasi di Great Barrier Reef Marine Park dan Commonwealth } \\
\text { National Parks; mendukung investasi bisnis, dan memberikan } \\
\text { bantuan arus kas untuk UKM. } \\
\text { Memberikan dukungan untuk investasi bisnis, misalnya, AUS } \$ 700 \\
\text { juta telah dialokasikan sehubungan dengan penghapusan aset } \\
\text { dengan ambang batas dari } \$ 30.000 \text { sampai } \$ 150.000 \text { dan } \\
\text { memperluas akses untuk memasukkan bisnis dengan omset tahunan } \\
\text { agregat kurang dari } \$ 500 \text { juta (naik dari } \$ 50 \text { juta) hingga } 30 \text { Juni } \\
\text { 2020. Langkah-langkah ini akan menyasar lebih dari } 3,5 \text { juta bisnis } \\
\text { (lebih dari } 99 \text { persen bisnis) yang mempekerjakan lebih dari } 9,7 \text { juta } \\
\text { karyawan. }\end{array}$ \\
\hline 5. & Prancis & $\begin{array}{l}\text { Pemerintah Prancis berjanji memberikan dukungan anggaran tanpa } \\
\text { batas untuk perusahaan dan pekerja. Untuk itu, pemerintah telah } \\
\text { menyiapkan Dana Solidaritas } € 2 \text { miliar, yang layak untuk diterima } \\
\text { oleh banyak bisnis Travel \& Tourism; Bisnis yang kegiatannya telah } \\
\text { ditutup seperti: bisnis katering (160.000), perdagangan non- } \\
\text { makanan (140.000), pariwisata (100.000); UKM yang telah } \\
\text { kehilangan omset sebesar } 70 \% \text { dibandingkan dengan Maret } 2019 \text {; } \\
\text { UKM dengan omset kurang dari } € 1 \text { juta. } \\
\text { Dalam rencana } € 45 \text { miliar, } € 8,5 \text { miliar euro telah didedikasikan } \\
\text { untuk pendanaan kerja paruh waktu/pengangguran parsial. Bagi } \\
\text { pekerja paruh waktu, perusahaan membayar kompensasi sebesar } 70 \% \\
\text { dari gaji kotor (sekitar } 84 \% \text { dari netto) kepada karyawannya. } \\
\text { Pekerjaan dengan upah minimum atau kurang mendapat kompensasi } \\
100 \% \text {. }\end{array}$ \\
\hline 6. & Singapura & $\begin{array}{l}\text { Pemerintah telah meluncurkan sejumlah kebijakan dan langkah- } \\
\text { langkah untuk mendukung sektor Travel \& Tourism dengan fokus } \\
\text { pada pembangunan kepercayaan dan memberikan bantuan kepada } \\
\text { sektor tersebut. Kebijakan tersebut meliputi: menghapuskan biaya } \\
\text { lisensi untuk hotel, agen perjalanan dan pemandu wisata, } \\
\text { meningkatkan pelatihan, dan menyubsidi mereka hingga 90\%; }\end{array}$ \\
\hline
\end{tabular}




\begin{tabular}{|c|c|c|}
\hline & & $\begin{array}{l}\text { memberikan dukungan gaji melalui Workforce Singapura sebesar } \\
70 \% \text { dari gaji bulanan tetap (dibatasi } \$ 2000 \text { per bulan per karyawan). } \\
\text { Menciptakan program pinjaman sementara untuk dukungan arus kas } \\
\text { dengan menerapkan potongan harga untuk pendaratan pesawat dan } \\
\text { biaya parkir serta potongan harga sewa untuk toko dan agen kargo } \\
\text { di Changi; menciptakan paket dukungan point-to-point untuk taksi } \\
\text { dan pengemudi mobil pribadi; skema Kredit Modal Kerja bagi } \\
\text { Perusahaan-SME, dan menerapkan potongan pajak penghasilan } \\
\text { perusahaan untuk YA2020 sebesar } 25 \% \text { dari hutang pajak, dibatasi } \\
\text { pada } \$ 15.000 \text { per perusahaan. }\end{array}$ \\
\hline 7. & UK & $\begin{array}{l}\text { Pemerintah telah menetapkan paket kebijakan sementara untuk } \\
\text { masyarakat, bisnis, dan layanan publik dengan alokasi anggaran } \\
\text { sebesar } £ 330 \text { miliar. Langkah-langkah tersebut meliputi: bebas tarif } \\
\text { selama } 12 \text { bulan untuk semua bisnis ritel, perhotelan; dana hibah } \\
\text { sebesar } £ 25.000 \text { untuk bisnis ritel, perhotelan, hospitality dengan } \\
\text { nilai rata-rata antara } £ 15.000 \text { dan } £ 51.000 \text {; dana hibah usaha kecil } \\
\text { sebesar } £ 10.000 \text { untuk semua bisnis kecil; Skema Pinjaman } \\
\text { Gangguan Usaha Coronavirus, yang menawarkan pinjaman hingga } \\
£ 5 \text { juta untuk UKM melalui British Business Bank; Pemerintah } \\
\text { akan memberikan jaminan kepada pemberi pinjaman } 80 \% \text { dari setiap } \\
\text { pinjaman kepada UKM, bisnis dapat mengakses } 12 \text { bulan tanpa } \\
\text { bunga dari keuangan skema keuangan tersebut. } \\
\text { Untuk mendukung perusahaan yang lebih besar, Bank of England } \\
\text { telah mengumumkan fasilitas pinjaman baru untuk meningkatkan } \\
\text { modal kerja dengan cara cepat, hemat melalui pembelian hutang } \\
\text { jangka pendek sehingga perusahaan secara fundamental akan tetap } \\
\text { kuat dan mampu membiayai kewajiban jangka pendeknya; Tidak ada } \\
\text { bisnis yang akan membayar PPN dari sekarang hingga akhir Juni; } \\
\text { Pemerintah juga membayar upah orang dengan skema baru. } \\
\text { Memberikan hibah sebesar } 80 \% \text { dari upah hanya sampai } £ 2.500 \\
\text { selama tiga bulan, dengan kemungkinan perpanjangan untuk semua } \\
\text { skala bisnis. Pembayaran pertama akan dilakukan pada akhir bulan } \\
\text { April. }\end{array}$ \\
\hline 8. & Phillipines & $\begin{array}{l}\text { Sektor Touris dan Travel akan menerima sebagian besar dari } \$ 523 \\
\text { juta. paket dukungan yang diberikan pemerintah untuk memerangi } \\
\text { wabah koronavirus. Khususnya, bantuan } \$ 271 \text { juta (PHP 14-miliar) } \\
\text { dari Infrastruktur Pariwisata dan Kewenangan Zona Perusahaan } \\
\text { (TIEZA) telah dialokasikan untuk berbagai program dan proyek } \\
\text { Departemen Pariwisata. Untuk mendukung pekerja, } \$ 23 \text { juta (PHP } \\
1,2 \text { miliar) dari Sistem Jaminan Sosial akan digunakan sebagai } \\
\text { tunjangan pengangguran untuk pekerja dari sektor swasta. } \\
\$ 58 \text { juta (PHP } 3 \text { miliar) akan didedikasikan untuk hibah beasiswa } \\
\text { untuk peningkatan dan pelatihan ulang pekerja yang dipindahkan } \\
\text { sementara. Hampir } \$ 40 \text { juta (PHP } 2 \text { miliar) juga akan dialokasikan } \\
\text { untuk program perlindungan sosial bagi pekerja yang bekerja di } \\
\text { organisasi yang terkena dampak COVID-19. Untuk } \\
\text { mempromosikan Filipina sebagai destinasi wisata setelah memasuki }\end{array}$ \\
\hline
\end{tabular}




\begin{tabular}{|c|c|c|}
\hline & & $\begin{array}{l}\text { fase pemulihan, Departemen Pariwisata (DOT) mengalokasikan } \\
\text { sekitar \$ } 118 \text { juta (PHP6 miliar). Setidaknya PHP421 juta } \\
\text { diperuntukkan bagi kampanye baru untuk perjalanan domestik dan } \\
\text { PHP467 juta untuk membuat konten yang menargetkan negara- } \\
\text { negara berkembang yang tidak terpengaruh oleh Covid }\end{array}$ \\
\hline 9. & Spain & $\begin{array}{l}\text { Pemerintah Spanyol mengumumkan pembiayaan } € 400 \text { juta dengan } \\
\text { jaminan dari ICO (Official Credit Institute of Spain), untuk wiraswasta } \\
\text { dan perusahaan pariwisata yang berdomisili di Spanyol yang } \\
\text { membutuhkan likuiditas dengan batas } € 500.000 \text {, termasuk } \\
\text { perusahaan transportasi , taksi, hotel, restoran, persewaan mobil, } \\
\text { agen perjalanan, museum dan sejenisnya. } \\
\text { Dana operasi sebagai pinjaman } 4 \text { tahun; dengan tingkat bunga tetap } \\
\text { (dengan maksimum 1,5\%) di mana ICO akan menjamin Lembaga } \\
\text { Kredit dengan 50\% risiko klien mereka. Operasi dapat disepakati } \\
\text { hingga } 31 \text { Desember } 2020 \text {. Pemerintah juga mengumumkan paket } € \\
200 \text { miliar pada } 17 \text { Maret untuk membantu perusahaan dan } \\
\text { melindungi pekerja dan kelompok rentan lainnya yang terkena } \\
\text { dampak krisis. Dari dana } € 200 \text { miliar, setengah dari uang itu terkait } \\
\text { dengan skema jaminan publik untuk memastikan likuiditas bagi } \\
\text { bisnis yang kesulitan, khususnya untuk meringankan kondisi PHK } \\
\text { kolektif sementara (dikenal sebagai ERTE di Spanyol), mendukung } \\
\text { pekerja dan bisnis yang terkena dampak penurunan aktivitas, dan } \\
\text { penjaminan likuiditas untuk bisnis. }\end{array}$ \\
\hline 10. & Portugal & $\begin{array}{l}\text { Pemerintah Portugal meluncurkan lebih dari } 30 \text { inisiatif yang } \\
\text { bertujuan untuk melindungi pekerja dan keluarga, dan mengurangi } \\
\text { dampak ekonomi Covid-19 melalui keringanan fiskal dan injeksi } \\
\text { likuiditas. Pemerintah telah memberikan perhatian khusus pada } \\
\text { sektor Tour and Travel dengan menetapkan batas kredit } € 60 \text { juta } \\
\text { yang didedikasikan untuk usaha mikro di sektor ini dan dengan } \\
\text { bekerja sama dengan Turismo de Portugal untuk meningkatkan } \\
\text { kapasitas nasional agar dapat menanggapi tantangan yang } \\
\text { dihasilkan dari Covid-19. } \\
\text { Langkah-langkah utama termasuk } € 200 \text { juta batas kredit untuk } \\
\text { bisnis, } € 60 \text { juta batas kredit untuk usaha mikro di sektor pariwisata, } \\
\text { dukungan luar biasa untuk pemeliharaan kontrak kerja di sebuah } \\
\text { perusahaan sebesar } 2 / 3 \text { dari remunerasi, dan memastikan } 70 \% \text { dari } \\
\text { Jaminan Sosial, sisanya ditanggung oleh pemberi kerja, menawarkan } \\
\text { beasiswa pelatihan di Institute for Employment and Vocational } \\
\text { Training di Portugal (IEFP) dan memperpanjang tenggat waktu } \\
\text { untuk pembayaran pajak dan kewajiban lainnya. }\end{array}$ \\
\hline
\end{tabular}

\section{Kesimpulan dan Rekomendasi}

Covid-19 berdampak besar hampir di semua aspek kehidupan termasuk sektor pariwisata karena meningkatnya pembatasan perjalanan, pembatalan acara besar dan keengganan untuk melakukan perjalanan internasional dan domestik. Untuk mengatasi badai ini, berbagai Negara berjuang keras untuk mengatasi dampak wabah Covid-19 selain koordinasi, tindakan penting untuk membatasi penyebaran pandemi Covid-19 dan mengatasi 
konsekuensi sosial-ekonomi adalah langkah2 seperti: penting memperhatikan rantai nilai produksi dan distribusi untuk memastikan kepastian pasokan yang diperlukan; memastikan bahwa pendapatan dan peluang kerja tidak terpengaruh oleh pandemi; dukungan pada perusahaan terdampak khususnya Usaha Kecil dan Menengah (UKM), koperasi, dan usaha sektor informal; terjaminnya supply dan ketersediaan stok pangan.

Kita harus merespon bersama untuk memperlambat penularan, memperkuat ketahanan sistem layanan kesehatan agar wabah Covid-19 dapat diatasi dengan cepat. Untuk itu perlu koordinasi/kerjasama semua pihak untuk mengatasi wabah ini. Ditengah upaya untuk mengendalikan penyebaran Covid-19, saatnya untuk memikirkan masa depan dan perencanaan pemulihan. Dengan memperhatikan berbagai dampak yang ditimbulkan dari wabah Covid-19, selain intervensi kebijakan yang telah dilakukan sebagaimana diuraikan diatas, masih perlu ada intervensi kebijakan lain dan mempelajari kebijakan dari berbagai negara khusus untuk memitigasi dampak Covid-19 di sektor pariwisata, maka direkomendasikan beberapa respon kebijakan sebagai berikut:

1. Melindungi Mata Pencaharian Pekerja. Bantuan keuangan harus diberikan untuk melindungi pendapatan jutaan pekerja dalam kesulitan besar.

2. Dukungan Fiskal, pemerintah harus memberikan keringanan kepada perusahaanperusahaan serta jutaan usaha kecil dan menengah di sektor pariwisata sebagai stimulus untuk mencegah mereka dari keruntuhan. Kewajiban-kewajiban kepada pemerintah dan tuntutan keuangan pada sektor pariwisata perlu dihapuskan dengan segera untuk setidaknya 12 bulan ke depan.

3. Injeksi likuiditas \& uang tunai, bantuan arus kas untuk mendukung pemain besar dan kecil dari sektor pariwisata yang sangat terdampak wabah covid-19.

4. Ada beberapa alternatif bantuan dana sosial dampak wabah covid-19 untuk 12 juta tenaga kerja di sektor pariwisata sebagai berikut: (1) bantuan dana sosial sebesar Rp. 38 triliun per bulan dengan upah minimum rata2 Rp. 2,91 juta; (2) Rp. 12,7 triliun per bulan untuk bantuan dana sosial Rp. 1 juta/orang/bulan; dan (3) Rp. 6,3 triliun per bulan untuk bantuan dana sosial sebesar Rp. 500 ribu/orang/bulan. Pilihan dari alternatif kebijakan disesuaikan dengan kemampuan keuangan Negara, dan partisipasi masyarakat dan dunia usaha. Bisa juga pilihan fokus pada salah satu atau dua lapangan usaha seperti fokus pada lapangan usaha penyediaan akomodasi, penyediaan makanan dan minuman.

ALTERNATIF PERKIRAAN KEBUTUHAN BANTUAN PENDANAAN UNTUK

TENAGA KERJA SEKTOR PARIWISATA TERDAMPAK COVID-19

\begin{tabular}{|c|c|c|c|c|c|c|c|c|}
\hline \multirow[t]{2}{*}{$\begin{array}{l}\mathbf{N} \\
\text { o. }\end{array}$} & \multirow[t]{2}{*}{ Lapangan Usaha } & \multirow{2}{*}{$\begin{array}{c}\text { Jumlah } \\
\text { (000 } \\
\text { orang) }\end{array}$} & \multicolumn{3}{|c|}{$\begin{array}{c}\text { Alternatif bantuan } \\
\text { dana } \\
\text { (ribuan) }\end{array}$} & \multicolumn{3}{|c|}{ Jumlah ( juta rupiah) } \\
\hline & & & $\begin{array}{c}\text { Rata2 } \\
\text { UM }\end{array}$ & BD1 & $\begin{array}{c}\text { BD } \\
2\end{array}$ & $3 \times 4$ & 3X5 & $3 X 6$ \\
\hline 1 & 2 & 3 & 4 & 5 & 6 & 7 & 8 & 9 \\
\hline 1 & Perdagangan & $4,682.5$ & 2,910 & $\begin{array}{r}1,00 \\
0\end{array}$ & 500 & $\begin{array}{r}13,626,07 \\
5\end{array}$ & $4,682,500$ & $2,341,250$ \\
\hline 2 & Angkutan & 71.0 & 2,910 & 0 & 500 & 206,610 & 71,000 & 35,500 \\
\hline 3 & Penyediaan Akomodasi & 917.1 & 2,910 & $\begin{array}{r}1,00 \\
0\end{array}$ & 500 & $2,668,761$ & 917,100 & 458,550 \\
\hline 4 & Penyediaan makanan minuman & $6,215.0$ & 2,910 & $\begin{array}{r}1,00 \\
0\end{array}$ & 500 & $\begin{array}{r}18,085,65 \\
0\end{array}$ & $6,215,000$ & $3,107,500$ \\
\hline 5 & Jasa agen perjalanan & 81.5 & 2,910 & $\begin{array}{r}1,00 \\
0\end{array}$ & 500 & 237,165 & 81,500 & 40,750 \\
\hline
\end{tabular}




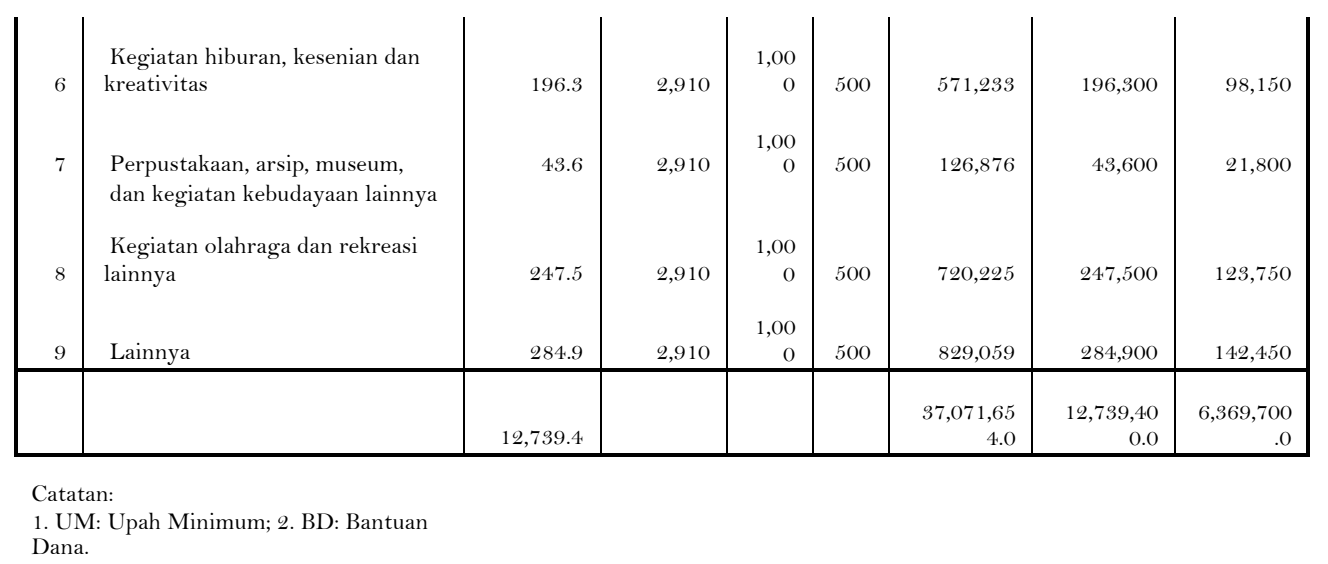

5. Perlu dibuat rancang bangun aplikasi sistem informasi pariwisata berbasis android didalamnya terdapat sekumpulan data industri pariwisata yang menyediakan data SDM pariwisata, jenis jasa, daya tarik, dan sarana wisata yang tersebar di Indonesia.

6. Menerapkan potongan harga untuk pendaratan pesawat dan biaya parkir serta potongan harga sewa untuk toko dan agen kargo di Bandara-bandara di Indonesia;

7. Menawarkan beasiswa pelatihan di Politeknik Pariwisata dan memperpanjang tenggat waktu untuk pembayaran pajak dan kewajiban lainnya.

8. Perlu rancang sumber-sumber pendanaan untuk penanggulangan bencana dengan cepat di sektor pariwisata seperti: skema pendanaan jangka pendek, skema Kredit Modal Kerja bagi UMKM, sektor informal, dan menerapkan potongan pajak penghasilan perusahaan.

9. Membentuk kelembagaan mitigasi bencana di sektor pariwisata di tingkat pusat sampai ke Kabupaten/Kota.

10. Menyusun buku pedoman standard baku tata kelola tentang perencanaan, pelaksanaan, dan pengendalian dampak wabah/bencana di sekkor pariwisata.

\section{Penutup}

Hanya dengan solidaritas dan solusi terkoordinasi di seluruh tanah air, kita akan mampu secara efektif mengelola keadaan darurat kesehatan masyarakat ini. Dibutuhkan solidaritas antar pemerintah pusat, propinsi, kabupaten/kota, dunia usaha, asosiasi-asosiasi industri pariwisata, perguruan tinggi, warga, dan media untuk membendung penyebaran virus, membantu pasien, dan untuk melawan keruntuhan ekonomi termasuk sektor pariwisata. Ini membutuhkan seperangkat langkah-langkah kebijakan strategis, dan konsisten. Kuncinya adalah kerja sama yang erat di antara semua aktor terkait.

\section{Daftar Pustaka}

https://www.aa.com.tr/id/nasional/bank-indonesia-ekonomi-indonesia-hanya-tumbuh-42-4-6-karena-covid-19/1771700

BPS, Neraca Satelit Pariwisata Nasional (NESPARNAS) 2017.

https://www.bps.go.id/website/images/Pariwisata-Rilis-Januari-2020-ind.jpg

Manulife Invetment Management, Investment Note 20 Maret, 2020.

https://www.eiu.com/n/covid-19-to-send-almost-all-g20-countries-into-a-recession/

https://www.unwto.org/impact-assessment-of-the-covid-19-outbreak-on-internationaltourism

https://wttc.org/en-gb/COVID-19/Government-Hub 